\title{
ASSESSMENT OF INGREDIENTS AND NUTRITIONAL VALUE OF VEGAN PRODUCTS IN LATVIAN MARKET
}

\author{
*Alla Mariseva, Ilze Beitane \\ Latvia University of Life Sciences and Technologies, Latvia \\ *Corresponding author's email: alla marisheva@inbox.lv
}

\begin{abstract}
Nowadays, veganism is becoming increasingly popular, because health concerns are usually the primary reason why people turn to vegan diet. The aim of the study was to identify the supply of vegan products on the Latvian market by analysing the ingredients used in the production of the products, nutritional and energy value of vegan products. 192 vegan products made in 20 different countries and available in online stores that offer their goods on the Latvian market were analysed. The research was carried out from January to March 2020. Information on the country of origin, ingredients, nutritional and energy value of the products was taken from product labels. The majority of the vegan products in Latvian online stores comes from Germany. The most important ingredient in the production in product groups such as meat substitutes and dairy alternatives is soya (Glycine max.), which provides high protein content. The vegan products could not be characterized as low in fat, as the average fat content in the various product

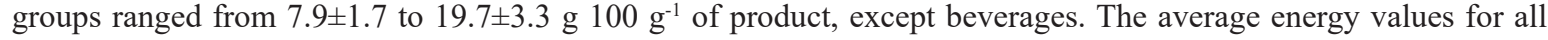
product groups varied between $210.7 \mathrm{~kJ} 100 \mathrm{~mL}^{-1}$ for beverages and $1226.0 \mathrm{~kJ} 100 \mathrm{~g}^{-1}$ for snacks. There would be a need for everyday vegan products in the Latvian market, as most of the products are snacks at the moment, and legumes should be used as ingredient in the production of new vegan products with increased nutritional value.

Key words: vegan products, ingredients, nutritional and energetic value.
\end{abstract}

\section{Introduction}

Nowadays, veganism is becoming increasingly popular, because it has been promoted by the Internet, newspapers, magazines and other media. This phenomenon has also been attracting the attention of the scientific community as it seemingly solves many health and environment related problems as well as poses many questions as to its benefits and faults. As veganism is not just a dietary pattern that excludes any animal-based foods (meat, fish, dairy products, eggs), it touches many other aspects of its practitioners' lives. A choice of becoming vegan can be motivated by many reasons. For example, this may be due to religious views or ethical concerns, environmentalism, family and cultural traditions, or it may be dictated by the practitioner's health condition or financial status, etc. (Perez, Moreira, \& Acevedo, 2015). Nevertheless, health concerns are usually the primary reason why people turn to vegan diet. For example, veganism can have a therapeutic or preventive effect on some chronic diseases. A number of studies have found that vegans have the lowest body mass index (BMI) compared with omnivores and vegetarians (Spencer et al., 2003). Lower BMI for vegans is explained by reduced intake of fat, especially trans- and saturated fatty acids. However, they have no lack of polyunsaturated fatty acids, e.g. linoleic and $\alpha$-linolenic acids, which are crucial for the human body. All the above mentioned values are connected with decreased insulin resistance and increased insulin secretion (Kahleova et al., 2019); thus, preventing the risk of developing type 2 diabetes (Petti et al., 2017). In addition, recent findings have reported that a vegetarian/vegan diet significantly lowers the risk of some cancers, cerebrovascular diseases as well as circulatory and ischemic heart diseases (Petti et al., 2017). In studies conducted in many countries, it has been discovered that the vegan diet contains less energy, what is often associated with a lower cardiometabolic risk - better low-density lipoprotein (LDL) cholesterol, fasting blood glucose and triglycerides, BMI and lipid variables (Dinu et al., 2017; Benatar \& Stewart, 2018; Lopez et al., 2019). A diet that excludes animalbased products no doubt impacts the bone health of its practitioners, the nature of this impact is yet to be discovered for some age groups. It has now been demonstrated that young adults are most likely to benefit from such a diet (Knurick et al., 2015). A study conducted in Asia in 2012 has given no confirmation of the fact that vegans were more prone to bone loss than omnivores, notwithstanding the higher rates in vitamin $\mathrm{D}$ deficiency and lower dietary calcium intakes in the former (Ho-Pham et al., 2012). From the gut microflora perspective, vegans present a unique profile where the presence of pathobionts seems to be reduced and the protective organisms seem to be of larger abundance. This leads to reduced levels of inflammation and can in turn enhance the protective health effect of the gut. There would need to be further research on the effect of such a diet in long-term and short-term (Glick-Bauer \& Yeh, 2014).

The Federal Commission for Nutrition (FCN) in Switzerland following an examination of the data of many nutritional studies reports that a wellbalanced vegan diet implies an appropriate choice of supplements with micronutrients and vitamins in order to avoid developing any serious deficiencies (Federal Commission for Nutrition, 2018). It has been well documented that vegetarian and vegan diets provide low amounts of calcium, vitamin $\mathrm{B}_{12}$ 
and D vitamin (Schüpbach et al., 2017) as well as n-3 Polyunsaturated Fatty Acids (PUFAs) and zinc, iron ( $\mathrm{Fe}^{2+}$ in particular), iodine (Petti et al., 2017) and vitamin A (Key, Appleby, \& Rosell, 2006). On the other hand, these dietary patterns are recognized as being rich sources of magnesium, vitamin $\mathrm{C}$ and folic acid, vitamin $\mathrm{B}_{1}$ and $\mathrm{B}_{6}$ (Schüpbach et al., 2017), vitamin E, n-6 PUFA, fibre and carotenoids (Key, Appleby, \& Rosell, 2006; Petti et al., 2017), as well as carbohydrates (Key, Appleby, \& Rosell, 2006).

In Latvia, vegan lifestyle is gaining in popularity. Reports from supermarket Maxima Latvia have shown a $150 \%$ growth in demand for vegan products in the year 2018 comparing to the year before (Savitska, 2019). According to the supermarket Rimi Latvia statistics, approximately $1 \%$ of their customers purchase vegan products on regular basis. Both supermarket chains have separate shelves in their stores dedicated solely to vegan products. Among them there is a variety of meat substitutes, cheese alternatives, sweets. Meat alternatives are regarded as a help to people in transition, if they find it difficult in the beginning to radically abstain from all varieties of meat products. They make the vegan lifestyle seem less restrictive (Twine, 2018). Consequently, major local food companies, such as 'Nuteko', 'Skriveru majas saldejums', 'Spilva', 'Valmiermuiza', 'Terapija', etc. are interested in developing ranges of vegan products that are being presented at an annual Latvian Vegan festival.

In 2007, the Ministry of Health of the Republic of Latvia has confirmed that the vegetarian and vegan diets are healthy and the plant-based diet can provide the necessary amount of nutrients to the human body (Ministry of Health, 2007). Ten years later, the Ministry of Health of the Republic of Latvia has released Healthy diet recommendations for vegetarians where vegans were mentioned as a subgroup (Ministry of Health, 2017).

The increased interest in vegan products is causing the growth of demand for these products on the market and, respectively, more and more companies are interested in producing these goods. The aim of the study was to identify the supply of vegan products on the Latvian market by analysing the ingredients used in the production of the products, nutritional and energy value of vegan products.

\section{Materials and Methods}

Within the framework of the study, 17 online stores were identified by analysing their offer. The stores that did not have a separate vegan and vegetarian section were immediately excluded from the research. As a next step, all stores that did not provide any information on the country of origin of their products, as well as the nutritional and energetic value, and complete ingredient lists, were excluded from the study. In total, only 4 online stores met the criteria for the study. Vegan products with more than one ingredient were selected for the study. In total, 192 vegan products made in 20 different countries and available in online stores, that offer their goods on the Latvian market were analysed. The research was carried out from January to March 2020. Information on the country of origin, ingredients, nutritional and energy value of the products was taken from product labels, descriptions in the online store. Product nutrition information included the amount of protein, fat, saturated fat, carbohydrates, sugars and sodium. All the analysed products were divided into seven groups: beverages, dairy alternatives, meat substitutes, flour products, snacks, sweets or desserts and other. The 'beverage' group contains products like rice, oatmeal, almond, coconut, soya and other type of beverages. 'Dairy alternatives' are mainly tofu and cheese alternatives. Vegan seitan and soya sausages, steak alternatives, soya patties and chops constitute the 'meat substitutes' group. Under the 'flour product' group such products as cakes, vegan bread, pizzas and lasagne are found. The 'snacks' group includes humus, pâtés and creams. Ice creams and berry flavoured desserts were placed in the 'sweets, desserts' group, whereas the remainder of products, for example, vegetable sauces, syrups, products made from vegetable fat were placed in the 'other' product group. The 'others' food group was excluded from the nutritional and energetic value analysis due to the large differences between the products. The data was processed in Microsoft Office Excel (Version: 14.0.7188.5002 (64-bit), calculating the mean value, standard error of the mean (SEM), minimum and maximum value for the nutritional and energetic value of the products.

\section{Results and Discussion}

The majority of the vegan products in Latvian online stores comes from Germany providing 33\% of the total vegan product offering (Figure 1). According to the market research company 'Mintel', in the last few years, Germany has been the leading vegan food producer in the world. In the time from 2013 to 2018 , the number of high-quality vegan products in Germany has increased by $240 \%$ (Domke, 2018; Mintel, 2018). The main target group for these products are flexitarians who do not altogether exclude animal products from their diet, but rather tend to include more vegan foods by reducing the consumption of animal products. Flexitarianism and ethical consumerism, among younger consumers in particular, have been found to be the key reasons of the vegan product growth in Germany (Coyne, 2018). About $35 \%$ of Germans say they understand the benefits of vegetarianism and over $60 \%$ of the 


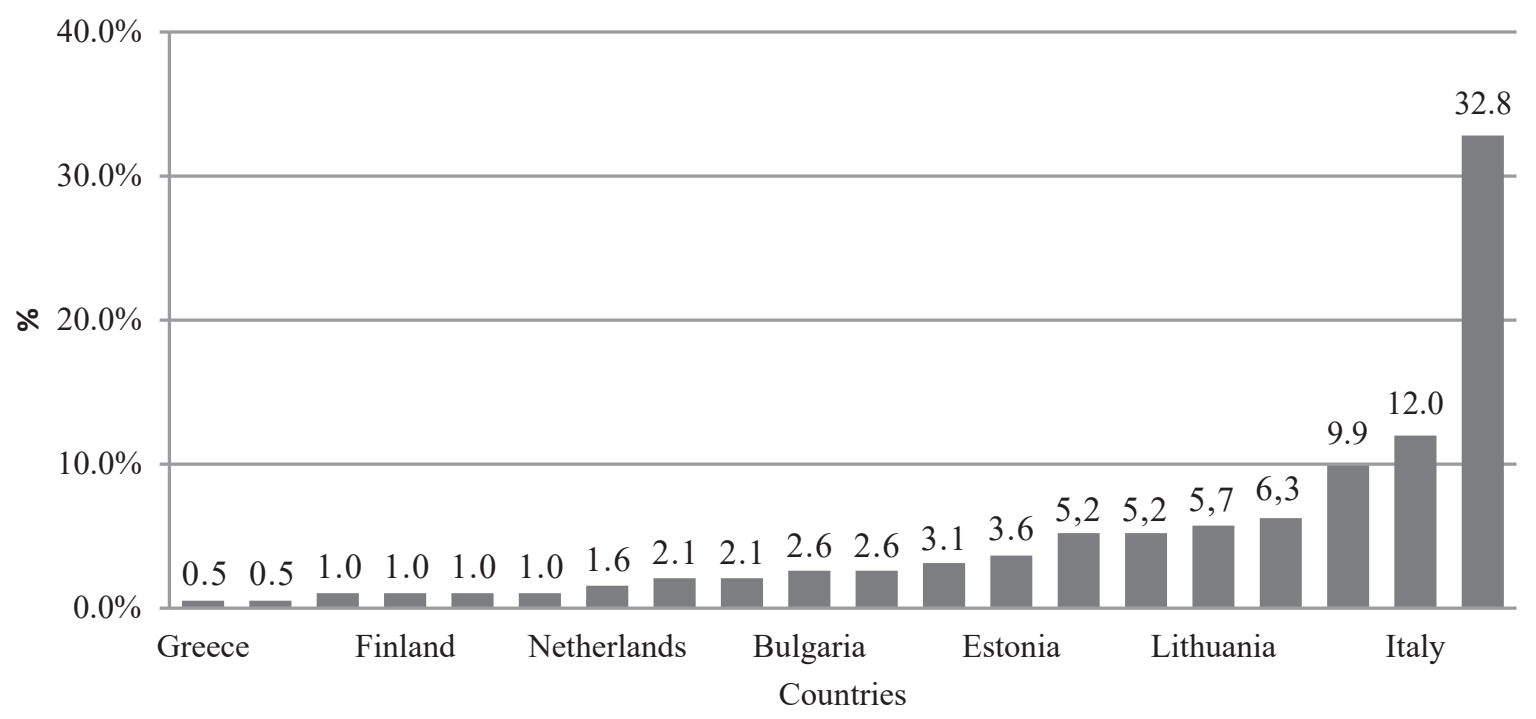

Figure 1. Proportion (\%) of vegan products by country of origin available in online stores.

population is consciously trying to consume less meat. German vegans are also known for their preference of natural, unprocessed and whole foods preferring products labelled 'no additives', 'organic', 'allergenfree' and 'gluten-free' (U.S. Department of Agriculture Foreign Agricultural Service, 2020).

As the next largest producer of vegan products on the Latvian market is Italy $(12.0 \%)$, followed by the Czech Republic (9.9\%), Belgium (6.3\%), Lithuania (5.7\%) and then Latvia and the UK with 5.2\%.

Analysing a vegan product by groups vegan snacks provided the largest part of the offer $(28 \%)$ followed by meat substitutes and dairy alternatives (Figure 2). Generally, vegan products cover all product groups. However, there are wide-ranging opportunities for producers to develop new vegan products that could provide a wholesome meal, considering that snacks are like a between meal not a daily diet.

The five most commonly used ingredients for vegan products were soya (Glycine max), starch, wheat (Triticum), pulses (Fabaceae), and oats (Avena sativa), where the main ingredient was soya, which was used in $48.4 \%$ of the vegan products. It was used in the production of meat substitutes like sausages and steaks; dairy alternatives like cheese alternatives; snacks; sweets, desserts; flour products and beverages (Figure 3).

Soybean's nutritional value makes them a potential replacement for dairy products, meat and fish. It is a source of high biological value protein, amino acids (tryptophan, lysine etc.), carbohydrates, fat as well as vitamins, minerals, dietary fibre, omega-3 fatty acids,

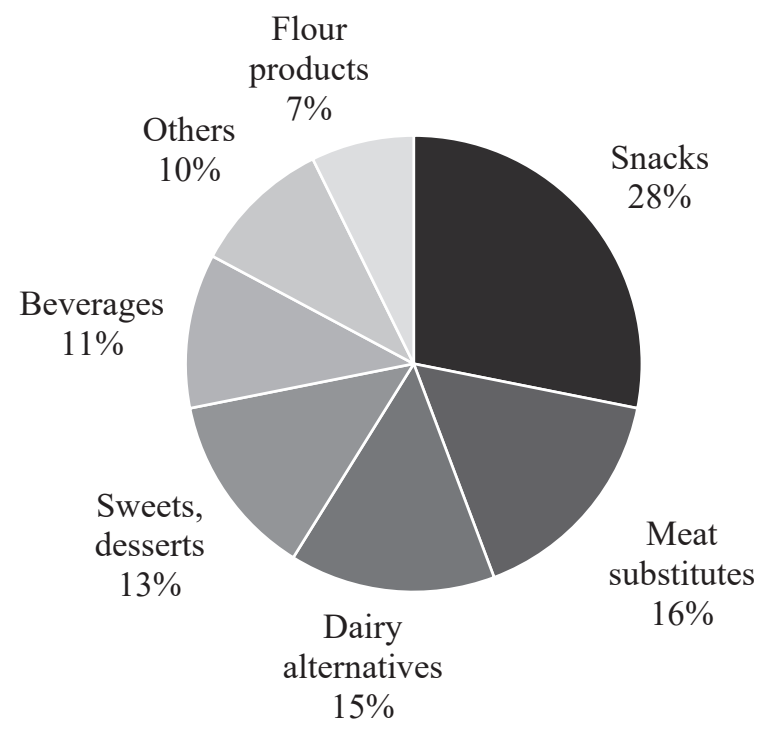

Figure 2. Vegan products by product groups available in online stores, $\%$. 


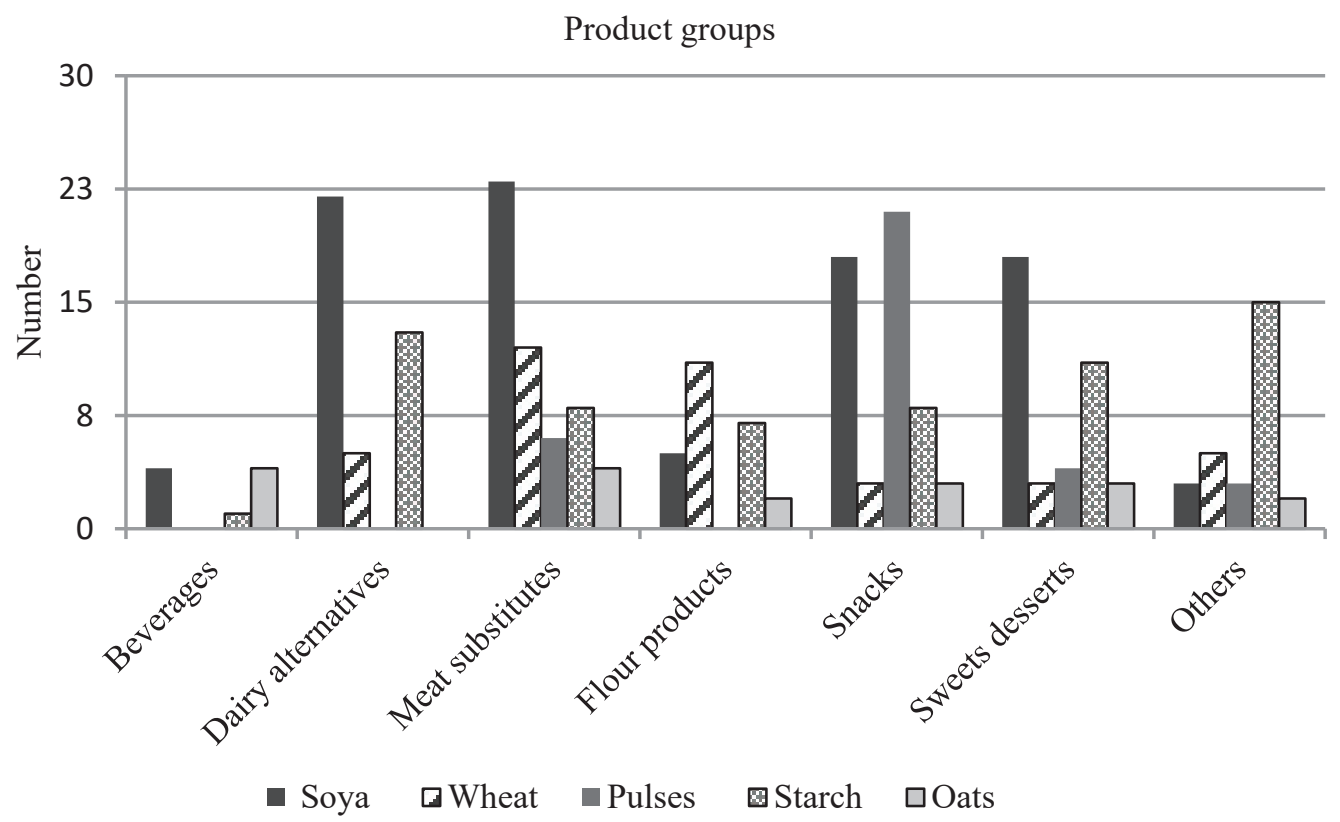

Figure 3. Most used ingredients in analysed vegan products available in online stores.

etc. All this, combined with a very reasonable price, makes processed soybean seeds a worthy alternative to animal protein sources (Sharma, Gupta, \& Joshi, 2015).

The second most commonly used ingredient was modified potato and corn starch $(32.8 \%)$ used in all product groups. The presence of starch enhances the energy value but not the nutritional value of the product. Manufacturers might consider other alternatives to starch using legume flour to increase the nutritional value of the products. Pulses (Fabaceae) were used as the main ingredient only in $17.7 \%$ of products, where most of them were snacks. A study on legume consumption in Latvia in 2014 showed that legumes, thanks to their high protein and other valuable nutrients, can significantly improve the diet of people who do not consume meat (Kirse \& Karklina, 2014).

After having analysed all the product labels, it should be noted that in $78 \%$ of the analysed products con- tain stabilizers and emulsifiers. These stabilizers and emulsifiers are mainly modified corn and potato starch, tapioca, as well as stabilizers like E 418 gellan gum, E 410 locust bean gum, E 412 guar gum, E 407 carrageenans and E 415 xanthan gum. In addition, thickeners like E 461 methylcellulose, E 471 monoand diglycerides of fatty acids, E 472e mono- and diacetyl tartaric acid esters of mono- and diglycerides, and E 482 calcium stearoyl lactate were used.

Within the framework of the study the nutritional and energy values of each product group were analysed: beverages and dairy alternatives (Table 2); flour products and snacks (Table 3); meat substitutes and sweets and desserts (Table 4).

In the vegan beverages group, $81.8 \%$ of products contained up to $1.5 \mathrm{~g}$ of fat per $100 \mathrm{~mL}$ and according to the Regulation (EU) No 1924/2006 (European Parliament \& Council, 2006) on nutrition and health claims made on foods complied with the nutrition

Nutritional and energy value of beverages and dairy alternatives, per $100 \mathrm{~mL}$ or $100 \mathrm{~g}$

\begin{tabular}{|l|c|c|c|c|c|c|}
\hline \multirow{2}{*}{} & \multicolumn{3}{|c|}{ Beverages, $\mathrm{n}=22$} & \multicolumn{3}{c|}{ Dairy alternatives, $\mathrm{n}=28$} \\
\cline { 2 - 7 } & Average \pm SEM & Min & Max & Average \pm SEM & Min & Max \\
\hline Energy, kJ & $210.7 \pm 44.8$ & 54.0 & 594.0 & $1029.3 \pm 194.6$ & 209.0 & 3495.0 \\
\hline Protein, g & $1.1 \pm 0.2$ & 0.1 & 4.0 & $9.7 \pm 1.4$ & 0 & 21.5 \\
\hline Fat, g & $1.3 \pm 0.1$ & 0.2 & 2.3 & $19.7 \pm 3.3$ & 2.3 & 93.7 \\
\hline Saturated fat, g & $0.5 \pm 0.2$ & 0 & 3.3 & $7.5 \pm 2.0$ & 0 & 40.1 \\
\hline Carbohydrates, g & $5.8 \pm 1.0$ & 0 & 13.0 & $7.6 \pm 1.5$ & 0.2 & 25.5 \\
\hline Sugars, g & $3.3 \pm 0.5$ & 0 & 28.3 & $1.2 \pm 0.4$ & 0 & 7.1 \\
\hline Sodium, g & $0.1 \pm 0.0$ & 0 & 0.2 & $1.0 \pm 0.2$ & 0 & 2.3 \\
\hline
\end{tabular}


Nutritional and energetic value of flour products and snacks per $100 \mathrm{~g}$

\begin{tabular}{|l|c|c|c|c|c|c|}
\hline \multirow{2}{*}{} & \multicolumn{3}{|c|}{ Flour products, $\mathrm{n}=14$} & \multicolumn{3}{c|}{ Snacks, $\mathrm{n}=54$} \\
\cline { 2 - 7 } & Average \pm SEM & Min & Max & Average \pm SEM & Min & Max \\
\hline Energy, kJ & $1116.6 \pm 102.1$ & 442.0 & 1778.0 & $1226.0 \pm 119.5$ & 400.0 & 7151.0 \\
\hline Protein, g & $8.0 \pm 1.4$ & 2.9 & 21.8 & $8.9 \pm 1.2$ & 1.1 & 42.6 \\
\hline Fat, g & $9.8 \pm 1.4$ & 2.0 & 18.0 & $19.3 \pm 1.2$ & 1.2 & 35.0 \\
\hline Saturated fat, g & $3.6 \pm 1.1$ & 0 & 11.5 & $3.1 \pm 0.4$ & 0 & 14.0 \\
\hline Carbohydrates, g & $36.6 \pm 4.4$ & 3.3 & 61.0 & $13.2 \pm 1.7$ & 1.5 & 66.0 \\
\hline Sugars, g & $6.7 \pm 2.5$ & 0 & 27.1 & $2.5 \pm 0.3$ & 0 & 9.0 \\
\hline Sodium, g & $1.1 \pm 0.2$ & 0 & 3.4 & $1.4 \pm 0.1$ & 0 & 7.0 \\
\hline
\end{tabular}

Nutritional and energy value of meat substitutes and sweets and desserts per $100 \mathrm{~g}$

\begin{tabular}{|l|c|c|c|c|c|c|}
\hline \multirow{2}{*}{} & \multicolumn{3}{|c|}{ Meat substitutes, $\mathrm{n}=30$} & \multicolumn{3}{c|}{ Sweets, desserts, $\mathrm{n}=25$} \\
\cline { 2 - 7 } & Average \pm SEM & Min & Max & Average \pm SEM & Min & Max \\
\hline Energy, kJ & $956.6 \pm 74.3$ & 212.0 & 1878.0 & $733.0 \pm 88.1$ & 305.0 & 1545.0 \\
\hline Protein, g & $22.4 \pm 2.4$ & 4.0 & 52.0 & $4.0 \pm 0.6$ & 0.9 & 12.0 \\
\hline Fat, g & $11.3 \pm 1.3$ & 0.4 & 33.0 & $7.9 \pm 1.7$ & 1.5 & 27.6 \\
\hline Saturated fat, g & $2.2 \pm 0.8$ & 0 & 22.0 & $4.7 \pm 1.3$ & 0.2 & 23.0 \\
\hline Carbohydrates, g & $7.5 \pm 0.8$ & 2.1 & 20.0 & $19.0 \pm 1.5$ & 9.4 & 32.0 \\
\hline Sugars, g & $1.9 \pm 0.3$ & 0 & 7.0 & $13.1 \pm 1.5$ & 0 & 26.0 \\
\hline Sodium, g & $1.2 \pm 0.1$ & 0 & 2.8 & $0.2 \pm 0.0$ & 0 & 0.8 \\
\hline
\end{tabular}

claim 'low in fat'. For $77.3 \%$ of products the sum of

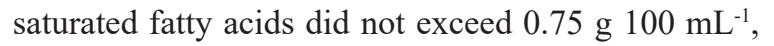
and these products could be labelled 'low in saturated fat'. The highest fat content was in the group of

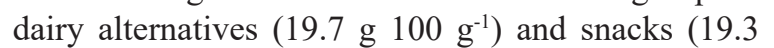
$\left.\mathrm{g} 100 \mathrm{~g}^{-1}\right)$, whereas the highest amount of saturated fat was in the group of dairy alternatives $(7.5 \mathrm{~g} 100$ $\left.\mathrm{g}^{-1}\right)$. In general, a vegan diet is characterized by low fat content, especially unsaturated fat. The study of Kahleova et al. (2019) showed that a 16-week vegan diet helped to reduce fat intake from $36.1 \%$ to $17.5 \%$ of total energy, reducing total fat by $48.9 \mathrm{~g}$ (from 77.7 to $28.8 \mathrm{~g}$ ). In addition, the fat mass of the participants, especially the internal fat, was reduced. With the exception of vegan beverages, the products selected in this study could not be characterized as low in fat, as the average fat content in the various product groups

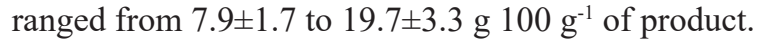

In the meat substitute group, the energy value was $956.6 \pm 74.3 \mathrm{~kJ} 100 \mathrm{~g}^{-1}$ with a protein content of

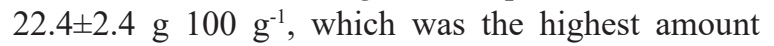
among all groups. The main sources of protein in the products were soya and legumes. The comparison of meat substitutes with poultry meat, which has an average energy value of $1278.2-1350.6 \mathrm{~kJ} 100 \mathrm{~g}^{-1}$ with

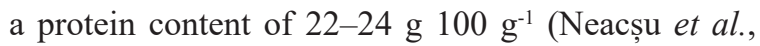
2016), showed that the protein content is equivalent while the energy value is lower, which is associated with lower fat content in meat substitutes. Although research showed that the amount of protein in the total energy intake for vegans constituted $13 \%$, whereas it was $17.5 \%$ for omnivores (Mariotti \& Gardner, 2019). However, there was no protein deficiency, except for a group of vegetarians, who, for some reason, excluded protein-rich plants like nuts, seeds, pulses, etc. from their diet.

It has been reported in the literature that meat substitutes were high in sodium, which is often an important factor in the development of many diseases (Curtain \& Grafenauer, 2019). This statement was confirmed in this study as meat substitutes had an

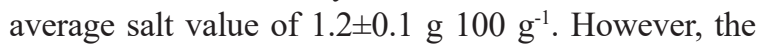
highest salt content was determined in snacks where the

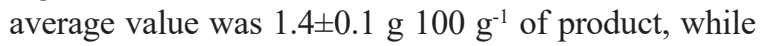
the maximum value was $7.0 \mathrm{~g}$ salt per $100 \mathrm{~g}$ of product.

Analysing the sugar content of vegan products, it was concluded that the highest content was in the group of sweets, desserts, with an average value of

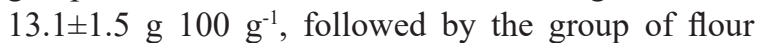

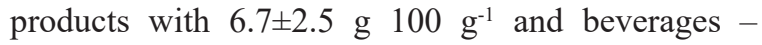




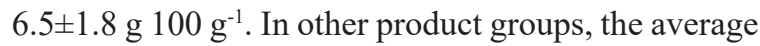
value of sugar content was less than $5 \mathrm{~g} 100 \mathrm{~g}^{-1}$ of product, which should be considered as a positive aspect.

The energy value of vegan products depended on the type of product, where the lowest value was $54.39 \mathrm{~kJ} 100 \mathrm{~mL}^{-1}$ of unsweetened almond-

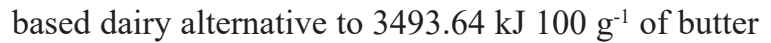
substitute. However, the average energy values for all product groups $\left(210.7 \pm 44.8 \mathrm{~kJ} 100 \mathrm{ml}^{-1}\right.$ for beverages - $1226.0 \pm 119.5 \mathrm{~kJ} 100 \mathrm{~g}^{-1}$ for snacks) supported the statements in the literature that a vegan diet is lower in energy compared to omnivores (Dinu et al., 2017; Benatar \& Stewart, 2018).

\section{Conclusions}

The study showed that vegan product offerings are diverse, covering different product groups but could be broader, offering more choice for consumers. Currently, Germany is the largest producer of vegan products in the world and in Europe, providing the largest supply of products also in Latvia. The most important ingredient in the production of vegan products is soya (Glycine max), which provided sufficient protein content in product groups such as meat substitutes and dairy alternatives. The nutritional and energy value of vegan products varied by product group. The average energy values for all product groups varied between

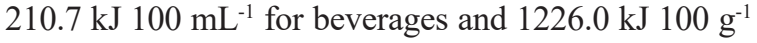
for snacks. For protein the average values ranged from

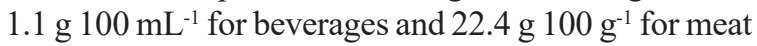

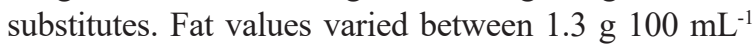

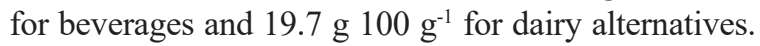

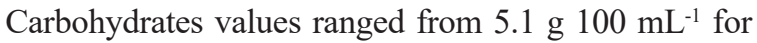

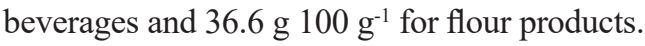

The study showed that at the moment there is a lack of basic everyday vegan products, as almost one third of all the products are snacks, and that legumes should be used as ingredients in the production of new vegan products with increased nutritional value.

\section{References}

Benatar, J.R., \& Stewart, R.A.H. (2018). Cardio metabolic risk factors in vegans: A meta-analysis of observational studies [Electronic version]. PLoS ONE, 13(12), 1-23. DOI: 10.1371/journal.pone.0209086.

Coyne, A. (2018). Germany vegan-food market deep-dive. part one - a perfect storm. Aroq - Just-Food.com (Global News). 10/27/2018. p1-1. 1p.

Curtain, F., \& Grafenauer, S. (2019). Plant-based meat substitutes in the flexitarian age: An audit of products on supermarket shelves. Nutrients, 11(11), 1-14. DOI: 10.3390/nu11112603.

Dinu, M., Abbate, R., Gensini, G.F., Casini, A., \& Sofi, F. (2017). Vegetarian, vegan diets and multiple health outcomes: A systematic review with meta-analysis of observational studies. Critical Reviews in Food Science and Nutrition, 57(17), 3640-3649. DOI: 10.1080/10408398.2016.1138447.

Domke, F. (2018). Vegetarian and vegan products - labelling and definitions. European Food and Feed Law Review: EFFL, 13(2), 102-107.

REGULATION (EU) No 1924/2006 OF THE EUROPEAN PARLAMENT AND COUNCIL (2006) European Parliament and Council. Retrieved March 12, 2020, from https:/eur-lex.europa.eu/legal-content/EN/TXT/ $\mathrm{PDF} /$ ?uri=CELEX:32006R1924\&from=en.

Federal Commission for Nutrition. (2018). Expert report of the FCN. Retrieved March 12, 2020, from https:// www.eek.admin.ch/eek/en/home/pub/vor-und-nachteile-vegane-ernaehrung.html.

Glick-Bauer, M., \& Yeh, M.C. (2014). The health advantage of a vegan diet: Exploring the gut microbiota connection. Nutrients, 6(11), 4822-4838. DOI: 10.3390/nu6114822.

Ho-Pham, L.T., Vu, B.Q., Lai, T.Q., Nguyen, N.D., \& Nguyen, T.V. (2012). Vegetarianism, bone loss, fracture and vitamin D: A longitudinal study in Asian vegans and non-vegans. European Journal of Clinical Nutrition, 66(1), 75-82. DOI: 10.1038/ejcn.2011.131.

Kahleova, H., Hlozkova, A., Fleeman, R., Fletcher, K., Holubkov, R., \& Barnard, N.D. (2019). Fat quantity and quality, as part of a low-fat vegan diet, are associated with changes in body composition, insulin resistance and insulin secretion. A 16-week randomized controlled trial. Nutrients, 11(3), 1-17. DOI: 10.3390/nu11030615.

Key, T.J., Appleby, P.N., \& Rosell, M.S. (2006). Health effects of vegetarian and vegan diets. Proceedings of the Nutrition Society, 65(1), 35-41. DOI: 10.1079/pns2005481.

Kirse, A., \& Karklina, D. (2014). Attitudes of Latvian adults to the consumption of pulses. In Research for Rural Development, 21-23. May 2014, Latvia University of Agriculture, Jelgava, 1, 130-137.

Knurick, J.R., Johnston, C.S., Wherry, S.J., \& Aguayo, I. (2015). Comparison of correlates of bone mineral density in individuals adhering to lacto-ovo, vegan, or omnivore diets: A cross-sectional investigation. Nutrients, 7(5), 3416-3426. DOI: 10.3390/nu7053416.

Lopez, P.D., Cativo, E.H., Atlas, S.A., \& Rosendorff, C. (2019). The Effect of Vegan Diets on Blood Pressure in Adults: A Meta-Analysis of Randomized Controlled Trials. The American Journal of Medicine, 132(7), 875-883.e7. DOI: 10.1016/j.amjmed.2019.01.044. 
Mariotti, F., \& Gardner, C.D. (2019). Dietary protein and amino acids in vegetarian diets-A review. Nutrients, 11(11), 1-20. DOI: 10.3390/nu11112661.

Ministry of Health (2007). Healthy eating tips for vegetarians. Retrieved March 12, 2020, from http://www. vm.gov.lv/images/userfiles/Tava\%20veseliba/ves_uztura_ieteik_vegetariesi.pdf.

Ministry of Health (2017). Veselīga uztura ieteikumi veǵetāriešiem (Healthy diet recommendations for vegetarians). Retrieved March 12, 2020, from http://www.vm.gov.lv/images/userfiles/Tava veseliba/ves uztura_ieteik_vegetariesi.pdf. (in Latvian).

Mintel. (2018, July). Germany continues to dominate global vegan new product development. Retrieved March 12, 2020, from https://www.mintel.com/press-centre/food-and-drink/germany-continues-to-dominateglobal-vegan-new-product-development.

Neacşu, M., Van, I., Popa, R., Popa, D., Vidu, L., \& Dronca, D. (2016). Research on the Assessment of Biochemical Parameters of Poultry Meat under an Identical Level of Energy and Protein. Scientific paper: Animal Science and Biotechnologies, 49(1), 217-222. Retrieved March 12, 2020, from http://web.b.ebscohost.com/ehost/ pdfviewer/pdfviewer?vid=1\&sid=5e216c39-e381-4380-a397-91c7d0bba8fc\%40sessionmgr 103 .

Perez, I., Moreira, C., \& Acevedo, C.R. (2015). Resistance to consumption and Veganism: A Study about Motivations, Values, and Feelings. Revista Gestão \& Tecnologia, 15(2), 50-67. DOI: 10.20397/21776652/2015.v15i2.621.

Petti, A., Palmieri, B., Vadalà, M., \& Laurino, C. (2017). Vegetarianism and Veganism: Not Only Benefits but also Gaps. A review. Progress in Nutrition, 19(3), 229-242. DOI: 10.23751/pn.v19i3.5229.

Savitska, J. (2019). Vegāniem produktu klāsts veikalos kḷūst plašāks, bet - vai tas ir pietiekams? (The range of products for vegans in stores is becoming wider, but is that enough?). [Electronic version]. Retrieved March 12, 2020, from https://www.lsm.lv/raksts/zinas/ekonomika/veganiem-produktu-klasts-veikalosklust-plasaks-bet--vai-tas-ir-pietiekams.a325544/. (in Latvian).

Schüpbach, R., Wegmüller, R., Berguerand, C., Bui, M., \& Herter-Aeberli, I. (2017). Micronutrient status and intake in omnivores, vegetarians and vegans in Switzerland [Electronic version]. European Journal of Nutrition, 56(1), 283-293. DOI: 10.1007/s00394-015-1079-7.

Sharma, D., Gupta, R., \& Joshi, I. (2013, November). Nutrient Analysis of Raw and Processed Soybean and Development of Value Added Soybean Noodles, 2014(1). Retrieved March 12, 2020, from https://www. researchgate.net/publication/275270297.

Spencer, E.A., Appleby, P.N., Davey, G.K., \& Key, T.J. (2003). Diet and body mass index in 38000 EPICOxford meat-eaters, fish-eaters, vegetarians and vegans. Internation Journal of Obesity, 27, 728-734. DOI: $10.1038 /$ sj.ijo.0802300.

Twine, R. (2018). Materially Constituting a Sustainable Food Transition: The Case of Vegan Eating Practice. Sociology, 52(1), 166-181. DOI: 10.1177/0038038517726647.

U.S. Department of Agriculture Foreign Agricultural Service. (2020). Germany is Leading a Vegalution - Vegan Revolution - in Europe. Retrieved March 12, 2020, from https://apps.fas.usda.gov/newgainapi/api/Report/ DownloadReportByFileName?fileName $=$ Germany $\% 20$ is $\% 20$ Leading $\% 20 \mathrm{a} \% 20$ Vegalution $\% 20 \% 20$ Vegan\%20Revolution\%20\%20in\%20Europe_Berlin_Germany_01-07-2020. 